\title{
PHYSICAL AND MECHANICAL PROPERTIES OF HYDROXYAPATITE CERAMICS WITH A MIXTURE OF MICRON AND NANO-SIZED POWDERS: OPTIMISING THE SINTERING TEMPERATURES
}

\author{
ADE INDRA*, ,GUNAWARMAN**, JON AFFI**, ISMET HARI MULYADI**, YOGI WIYANTO** \\ * Department of Mechanical Engineering, Institut Teknologi Padang, \\ Kp Olo, Padang, 25143, Indonesia \\ **Department of Mechanical Engineering, Universitas Andalas, \\ Limau Manis, Padang, 25163, Indonesia \\ \#E-mail: gunawarman@eng.unand.ac.id
}

Submitted April 15, 2021; accepted May 17, 2021

\begin{abstract}
Keywords: Ceramic bodies, Pellet-shaped hydroxyapatite, Grain growth, High temperature phase
In order to determine the optimum sintering temperatures of hydroxyapatite ceramic sintered bodies, while maintaining high physical and mechanical properties, pellet-shaped hydroxyapatite (HA) samples were prepared by controlling micron-and nano-sized powders. Determining the optimum sintering temperature aims to avoid changes in the HA phase and reduce excessive grain growth at too high temperatures. The samples were made by mixing micron- and nano-sized HA powders at a ratio of 80:20 wt. \% and adding polyvinyl alcohol (PVA) of $10 \mathrm{wt} . \%$ as a binder. Green bodies were made using the uniaxial pressing method under a pressure of $200 \mathrm{MPa}$. The initial heating was carried out at a temperature of $700{ }^{\circ} \mathrm{C}$ for $1 \mathrm{~h}$ to remove the $\mathrm{PVA}$, followed by a sintering process performed at temperatures ranging from $1000^{\circ} \mathrm{C}$ to $1200^{\circ} \mathrm{C}$ with a holding time of $2 \mathrm{~h}$. The results showed that the optimum sintering temperatures ranged from $1150{ }^{\circ} \mathrm{C}$ to $1200{ }^{\circ} \mathrm{C}$, with no significant linear shrinkage occurring at those temperatures. In the microstructural analysis, a significant decrease occurred in the number of pores in the sintered bodies at a temperature of $1200^{\circ} \mathrm{C}$. The mechanical properties are maintained at a high level at sintering temperatures of $1150^{\circ} \mathrm{C}$ and $1200^{\circ} \mathrm{C}$, i.e., Vickers hardness values of $4.40 \mathrm{GPa}$ and $5.67 \mathrm{GPa}$, respectively.
\end{abstract}

\section{INTRODUCTION}

Hydroxyapatite (HA) or $\mathrm{Ca}_{10}\left(\mathrm{PO}_{4}\right)_{6}(\mathrm{OH})_{2}$ is a bioceramic with excellent biocompatibility [1-5]. As a bioactive material with a ratio of calcium and phosphorus that resembles natural bone, it is ideal as a bone implant candidate [6-11]. However, it is also classified as a ceramic, which is very fragile and unstable under pressure and has low strength [12-15]. These drawbacks have encouraged researchers to conduct further studies to improve its mechanical properties.

Researchers have tried many different ways to improve the mechanical properties of HA sintered bodies, including making HA-based composites by adding strengthening materials [16], adjusting the pressure when making green bodies [17], and adding binding materials of specified amounts and types [18]. An HA-based composite with $\mathrm{Al}_{2} \mathrm{O}_{3}$ as a strengthening material sintered at $1200{ }^{\circ} \mathrm{C}$ has been proven to increase the compressive strength [19]. Another composite with $\mathrm{MgF}_{2}$ sintered at $1150{ }^{\circ} \mathrm{C}$ has also been found to increase the hardness and fracture toughness [20]. In the process of making green bodies, the level of uniaxial pressing can affect the mechanical properties of ceramic-based products [21]. The addition of binders, in proper amounts and types, affects those of HA sintered bodies. Commonly used binders include polyvinyl alcohol (PVA), polyacrylamide (PAM), and polyvinylpyrrolidone (PVP). These three types of binders have excellent biocompatible properties and do not interact negatively with HA. PVA binders show better strength in resisting erosion by the Simulated body fluid (SBF) test method [22].

Other factors that influence mechanical properties are the particle shape, particle size, and particle-size distribution [23]. In previous studies, the distribution of controlled-sized powders, namely, in microns and nanosized, aimed at improving the mechanical properties of HA sintered bodies have been studied. The results showed a significant increase in the compressive strength, along with the addition of a nano-sized powder. The strengthening mechanism was found to occur in the form of a reduction in the pore size when the nanosized powder filled the gaps between the micron-sized ones, causing the strength of the HA sintered bodies to increase [24].

The sintering temperature is also an important factor that should be considered for obtaining a biocompatible ceramic. A high sintering temperature has the potential to affect the phase change of HA [25] and the grain growth which causes a decrease in the mechanical pro-perties [26]. However, the sintering temperature can be adjusted by controlling the size of the powders, where a smaller 
powder size helps to achieve a lower sintering temperature in making sintered bodies. The sintering temperature of a nano-HA with an average size of $250 \mathrm{~nm}$ is around $1000{ }^{\circ} \mathrm{C}$ [27]. The sintering temperature of HA with a micro-size of $2.5 \mu \mathrm{m}$ is $1250{ }^{\circ} \mathrm{C}[25,28]$. Such a micron-HA powder is easier to find at a low cost. However, the sintered body manufacturing process must be sintered at high enough temperatures because it has a high specific surface energy [29]. A nano-HA powder can be sintered at low temperatures, where a phase change can be avoided and has better mechanical properties. However, it has several disadvantages, such as a relatively high cost [30]. Therefore, a mixture of micronand nano-sized HA powders at a controlled ratio has the potential to reduce the sintering temperature. Which is ultimately thought to be able to retain the phase of the $\mathrm{HA}$ and, at the same time, to maintain a high strength in the HA bodies.

In this study, the aim was to optimise the sintering temperature of a mixture of micron- and nano-sized HA powders at a controlled ratio. The sintering temperature was varied, then the HA sintered body was evaluated including the phase, grain growth, physical and mechanical properties.

\section{EXPERIMENTAL}

\section{Materials}

The bioceramic used in this study was a commercial analytical HA with a specification of $2.5 \pm 0.5 \mu \mathrm{m}$ and the $200 \mathrm{~nm}$-sized powders were obtained from SigmaAldrich Co in the United States. A liquid PVA obtained from Jaya Kimia in Indonesia was used as a binder. All the materials were employed directly without any preliminary treatment. Pure water obtained from Brataco in Indonesia was used during the entire research process.

\section{Methods}

\section{Sample preparation}

HA powders with sizes of $2.5 \mu \mathrm{m}$ and $200 \mathrm{~nm}$ were mixed at a ratio of $80: 20 \mathrm{wt} . \%$, in a rotary drum mixer (drum size: diameter $=40 \mathrm{~mm}$; length $=55 \mathrm{~mm}$; PMME-Lab.itp; rotation $=100 \mathrm{rpm}$ ) equipped with steel balls (diameter $=4.8 \mathrm{~mm}$; unit number $=20$ ) for $2 \mathrm{~h}$. A PVA of $10 \mathrm{wt} . \%$ was used as a binder and added into the mixture for $1 \mathrm{~h}$. Green bodies with a diameter of $8 \mathrm{~mm}$ and thickness of $5 \mathrm{~mm}$ were made with uniaxial pressing at a pressure of $200 \mathrm{MPa}$. The initial heating was carried out at a temperature of $700{ }^{\circ} \mathrm{C}$ for $1 \mathrm{~h}$ to remove the PVA, followed by a sintering process performed at varying temperatures of $1000{ }^{\circ} \mathrm{C}, 1050{ }^{\circ} \mathrm{C}, 1100{ }^{\circ} \mathrm{C}$, $1150{ }^{\circ} \mathrm{C}$, and $1200^{\circ} \mathrm{C}$ with a holding time of $2 \mathrm{~h}$ in an air environment. An illustration of a sample preparation can be seen in Figure 1.
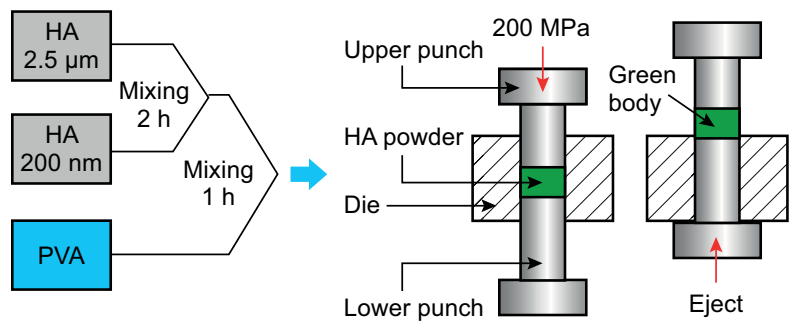

Mixing process

Unaxial pressing process
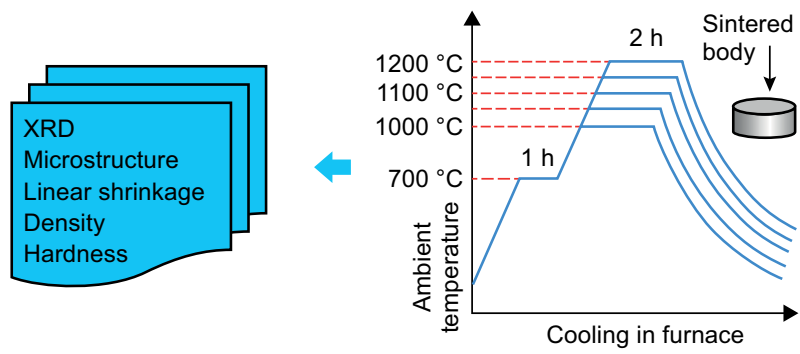

Physical and mechanical

Sintering process (5 temperatures variations)

Figure 1. Illustration of the sample preparation and testing.

\section{Sample characterisation}

The characterisation of the HA powder crystalline phase was carried out using X-Ray Diffraction (XRD PANalytical, Type PW3040/60, Netherlands). The working conditions of the XRD on the $\mathrm{Cu}$ anode material were at $40 \mathrm{kV}$ and $30 \mathrm{~mA}(\mathrm{CuK} \alpha, \lambda=1.54060 \AA$, $2 \theta=10-100)$. The scan time was set at 7.14 seconds. The analysis was carried out using a qualitative method, that is, by comparing the pattern of the peaks of the test results with the International Centre for Diffraction Data (ICDD). The linear shrinkage test was performed by comparing the weights and diameters of both the green and sintered bodies, with twelve samples for each sintering temperature variation. The observations of the microstructures were carried out using Field Emission Scanning Electron Microscopy (FESEM - FEI Inspect F50). The observation was made on the HA powders, aiming to see the shape, distribution, and size of the powders, and on the HA sintered body to see the effect of the sintering temperature on the bonds between the grains. The analysis of the powder size distribution and grain size distribution of the sintered body was carried out using ImageJ software. The actual density test was performed using the Archimedes method with twelve samples for each sintering temperature variation, while the relative density was calculated by comparing the actual density with the theoretical density of the HA. The theoretical density of the HA set was $3.156 \mathrm{~g} \cdot \mathrm{cm}^{-3}$ [31-33]. Vickers micro testing machines (HMV Shimadzu, Japan) were used for the Vickers hardness test, with an indentation load of $9.8 \mathrm{~N}$. Before the hardness test, 10 samples were polished for each sintering temperature variation. 


\section{RESULTS AND DISCUSSION}

\section{XRD characterisation}

The comparison of the XRD test results on the green body and the sintered body is shown in Figure 2. In Figure $2 b$, the green body shows two phases, the HA and PVA. The HA and PVA phases were analysed using qualitative methods, namely comparing them with the

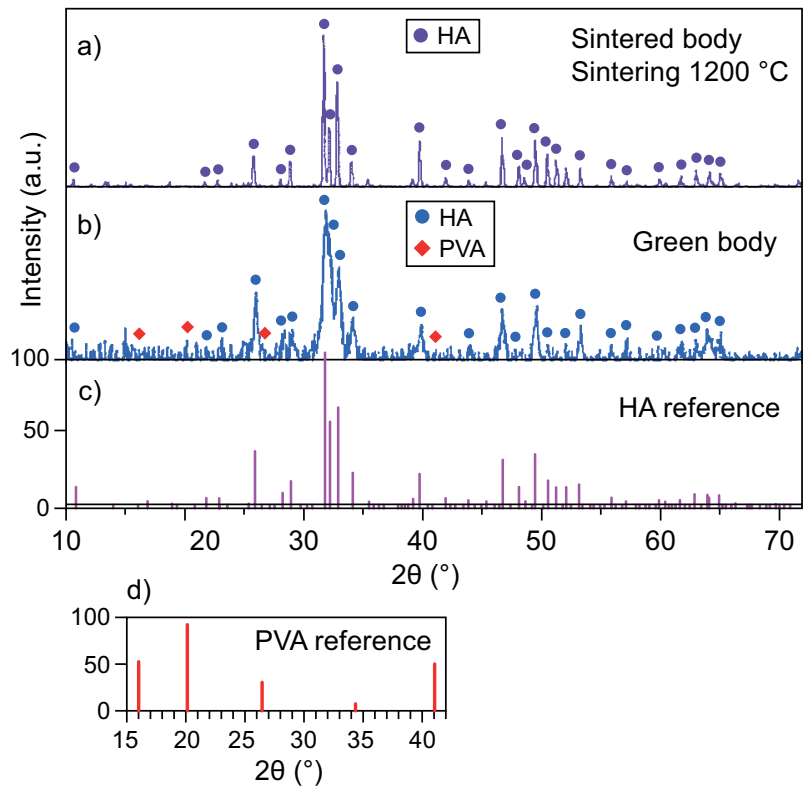

Figure 2. XRD pattern on the HA sintered body (a), green body (b), comparative HA (c), reference pattern 01-075-9526, and comparative PVA (d), reference pattern 00-057-1934.

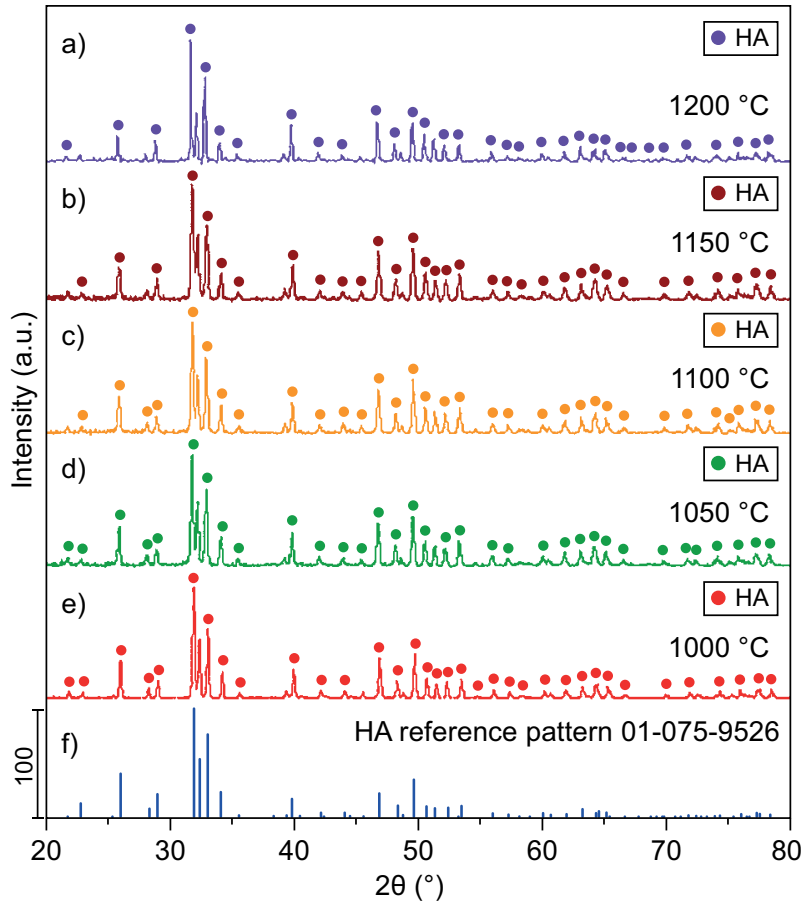

Figure 3. XRD pattern on the HA sintered body with variations in the sintering temperatures (a-e), comparative HA (f), reference pattern 01-075-9526. respective ICDD reference patterns 01-075-9526 and 00-057-1934, respectively. The HA and PVA phases were found at their main peaks at the $2 \theta$ angles of $31.82^{\circ}$ and $20.17^{\circ}$, respectively. In Figure $2 \mathrm{a}$, the PVA phase was not found on the sintered body. It is suspected that the PVA is lost during the sintering process. In previous studies, it was reported that the melting point of PVA, which was tested by differential scanning calorimetry (DSC), was found at a temperature of $204.3{ }^{\circ} \mathrm{C}$. While the PVA was completely burned out at temperatures above $600{ }^{\circ} \mathrm{C}$ [34]. In a separate test, the PVA heating and melting process has been carried out in a furnace, where the PVA completely burns out at a temperature of $600-700{ }^{\circ} \mathrm{C}$. The XRD test results on the HA sintered body are shown in Figure 3. All the major peaks have similarities in terms of the position of $2 \theta$ for all the sintering temperature variations, as well as when compared with the HA of the ICDD reference pattern 01-075-9526. The characterisation of the crystalline phase of the HA sintered bodies shows that there was no phase change at sintering temperatures ranging from 1000 to $1200{ }^{\circ} \mathrm{C}$. These results are also the same as those reported in previous studies $[35,36]$. Another study also reported that there was no change in the phase of the HA sintered body at sintering temperatures ranging from $1050{ }^{\circ} \mathrm{C}$ to $1250{ }^{\circ} \mathrm{C}$. However, there was a new phase, that is, $\alpha$-TCP, at $1300{ }^{\circ} \mathrm{C}[37]$.

\section{Characteristics of the microstructure}

The characterisation of the mixed micron- and nano-sized HA powders with a ratio of $80: 20 \mathrm{wt} . \%$ is shown in Figure 4a. The micron- and nano-sized HA powders are in micro-spherical and nano-spherical forms [38-40]. The distribution of the mixture of the micronand nano-sized HA powders occurred homogeneously. Figure 5a shows the analysis of the HA powder size distribution using ImageJ software. The micron-sized powders with a distribution $>2 \mu \mathrm{m}$ are $32 \%$ and the others are $1-2 \mu \mathrm{m}$ in size. Whereas the nano-sized powders with a distribution $<300 \mathrm{~nm}$ are $20 \%$ and the others are at a powder size of $300-600 \mathrm{~nm}$. The characterisation of the HA sintered body for all the sintering variations can be seen in Figure 4. Figure $4 \mathrm{~b}$ shows the bodies sintered at a temperature of $1000^{\circ} \mathrm{C}$, in which very large pores were seen in the FESEM image, indicating that the sintering process has not yet occurred well. The FESEM image of the HA bodies sintered at $1000{ }^{\circ} \mathrm{C}$ shows similarities to the results reported in several previous studies [41-44], indicating the existence of many pores. Figure $4 \mathrm{c}$ shows bodies sintered at a temperature of $1050{ }^{\circ} \mathrm{C}$, in which the FESEM image shows a decrease in the number of pores. Moreover, at a sintering temperature of $1050{ }^{\circ} \mathrm{C}$, the growth of the grains was seen in the nano-sized HA powder as a result of the sintering temperatures ranging from 800 and $1000{ }^{\circ} \mathrm{C}$ [27]. Figure $4 d$ depicts the bodies sintered at $1100^{\circ} \mathrm{C}$. This sample shows a very significant 


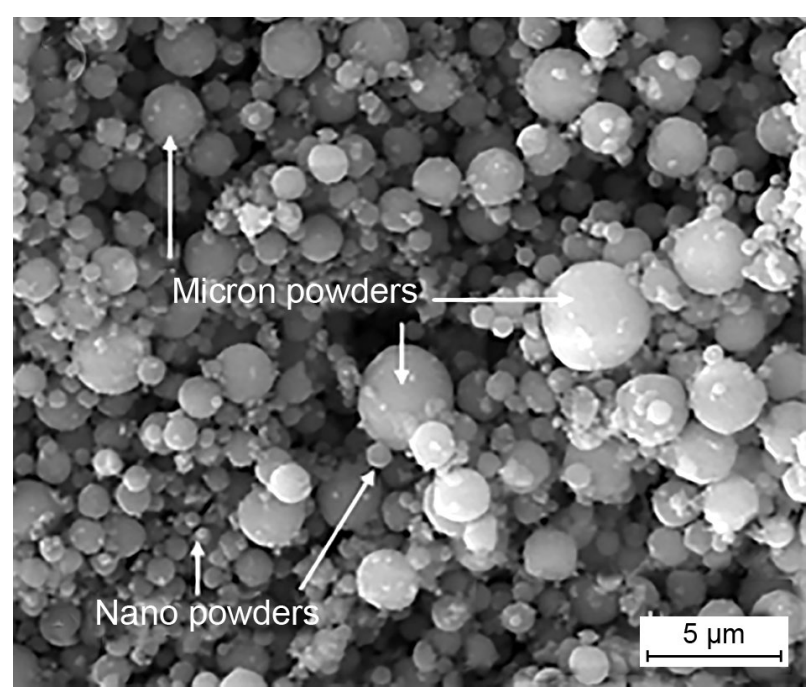

a) HA powders

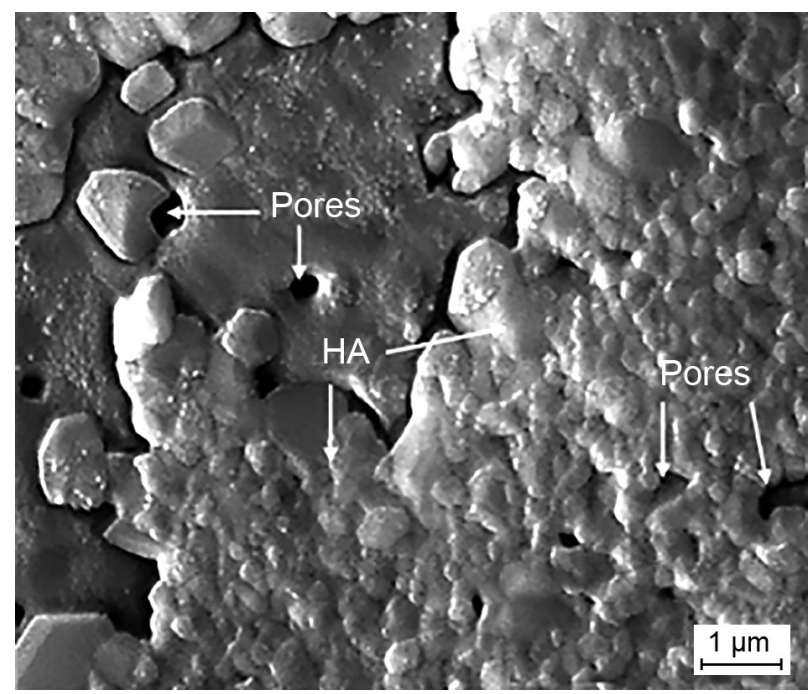

c) $1050{ }^{\circ} \mathrm{C}$

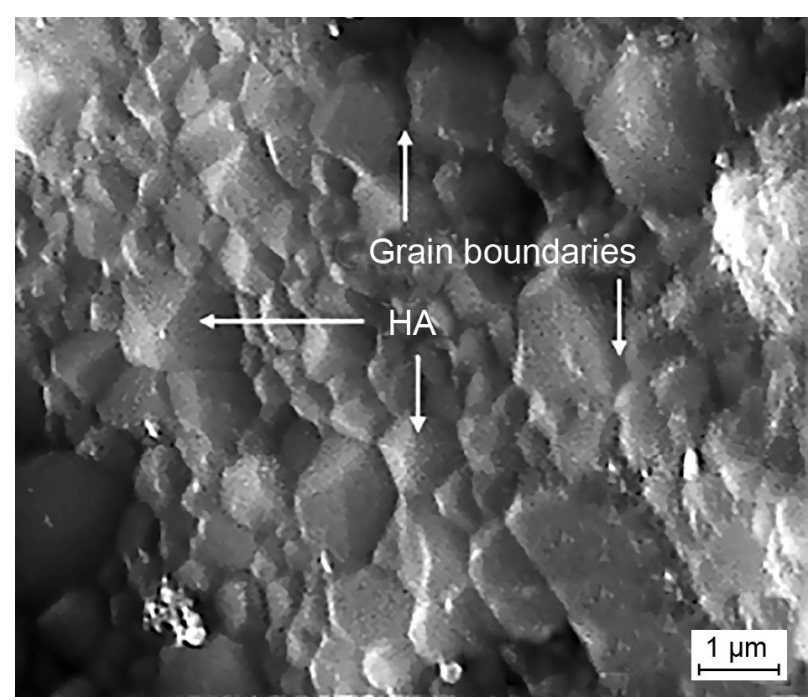

e) $1150{ }^{\circ} \mathrm{C}$

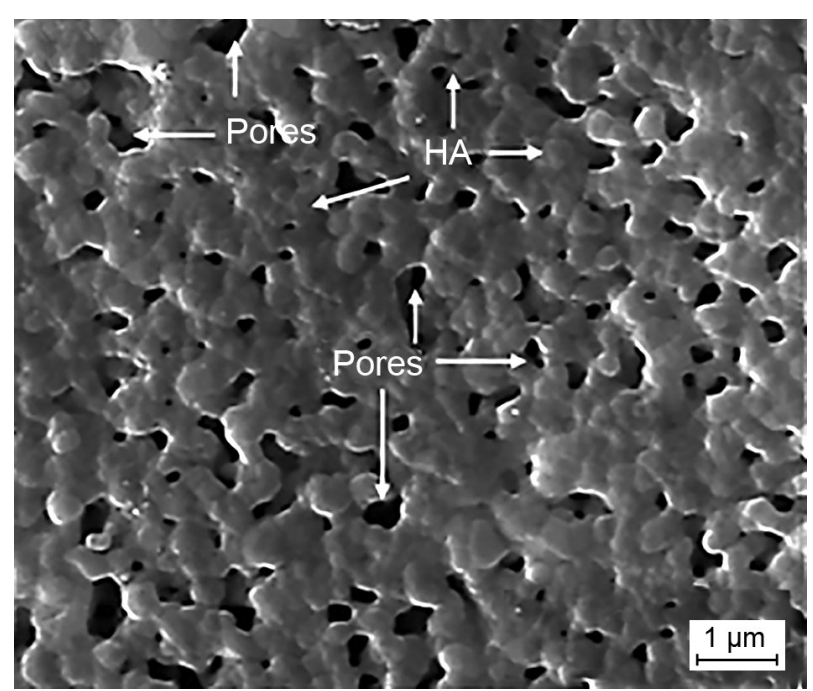

b) $1000^{\circ} \mathrm{C}$

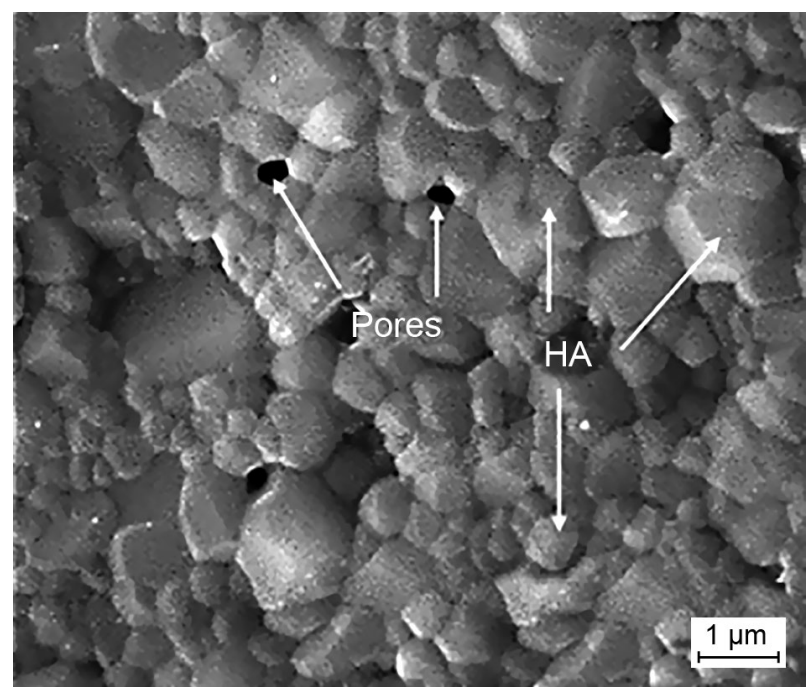

d) $1100^{\circ} \mathrm{C}$

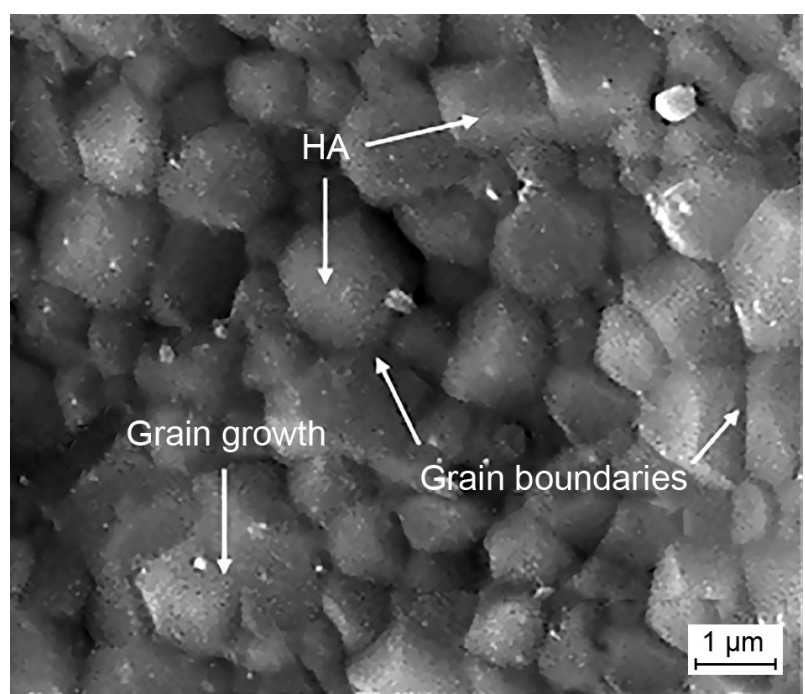

f) $1200{ }^{\circ} \mathrm{C}$

Figure 4. FESEM image: a) micron- and nano-sized HA powders (ratio of 80:20 wt. \%) and the HA sintered bodies with variations in the sintering temperatures: b) $1000^{\circ} \mathrm{C}$, c) $1050^{\circ} \mathrm{C}$, d) $1100^{\circ} \mathrm{C}$, e) $1150{ }^{\circ} \mathrm{C}$, f) $1200^{\circ} \mathrm{C}$. 
decrease in the number and size of the pores. Most of the micron-sized HA powder formed like bonds of grains. An image similar to this was also reported in the previous study [45]. Figure $4 \mathrm{e}$ exhibits bodies sintered at $1150{ }^{\circ} \mathrm{C}$. The FESEM image proves that the number of pores was very small and ae almost invisible. In this condition, it is assumed that the sintering temperature had been reached, but was not perfect. In Figure $4 \mathrm{f}$, the bodies were sintered at $1200{ }^{\circ} \mathrm{C}$, in which the sintering process had occurred perfectly. The FESEM image confirms that there are no pores between the HA particles. Therefore, it can be concluded that the sintering temperature on the micron- and nano-sized HA powders with a ratio of $80: 20 \mathrm{wt} \%$ ranged from 1150 to $1200{ }^{\circ} \mathrm{C}$. Figure $5 \mathrm{~b}-\mathrm{d}$ shows the analysis of the grain size distribution of the HA sintered body using Image J software. The grain size distribution was analysed for the sintering temperatures

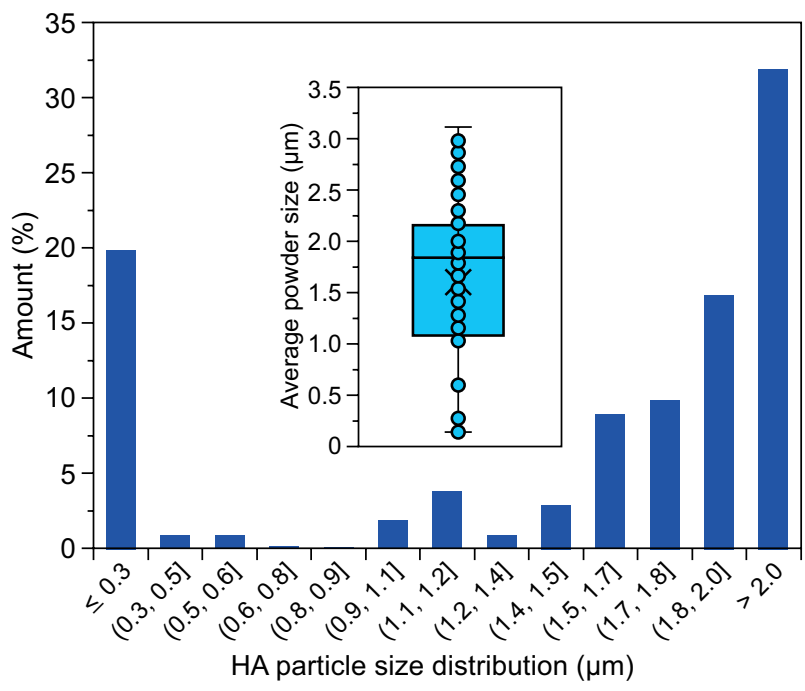

a)

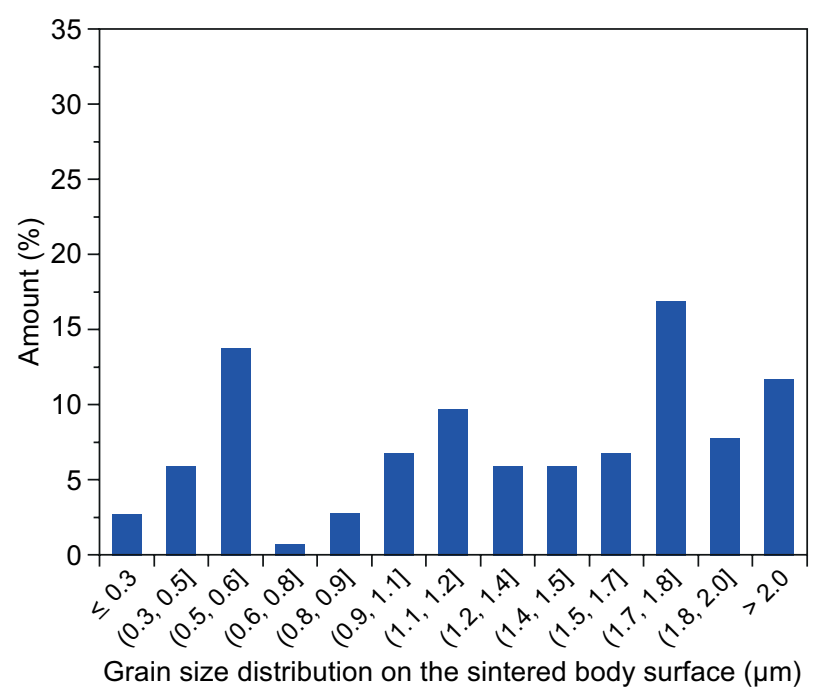

c) of $1100{ }^{\circ} \mathrm{C}$ and $1200{ }^{\circ} \mathrm{C}$, because it can show differences in the grain growth after the sintering process. Figure $5 \mathrm{~b}$ and c shows the occurrence of grain growth with an increasing sintering temperature from 1100 to $1200{ }^{\circ} \mathrm{C}$. This is evidenced by Figure $5 \mathrm{~d}$, where the average grain size value increases with the increasing sintering temperature.

\section{Linear shrinkage}

The linear shrinkage testing was carried out using two methods, namely diameter shrinkage and weight shrinkage. The linear shrinkage value was calculated by comparing the green bodies with the sintered ones, followed by calculating the average value. Figure 6 indicates an increase in the percentage value of the shrinkage diameter as the sintering temperature increases. The dia-

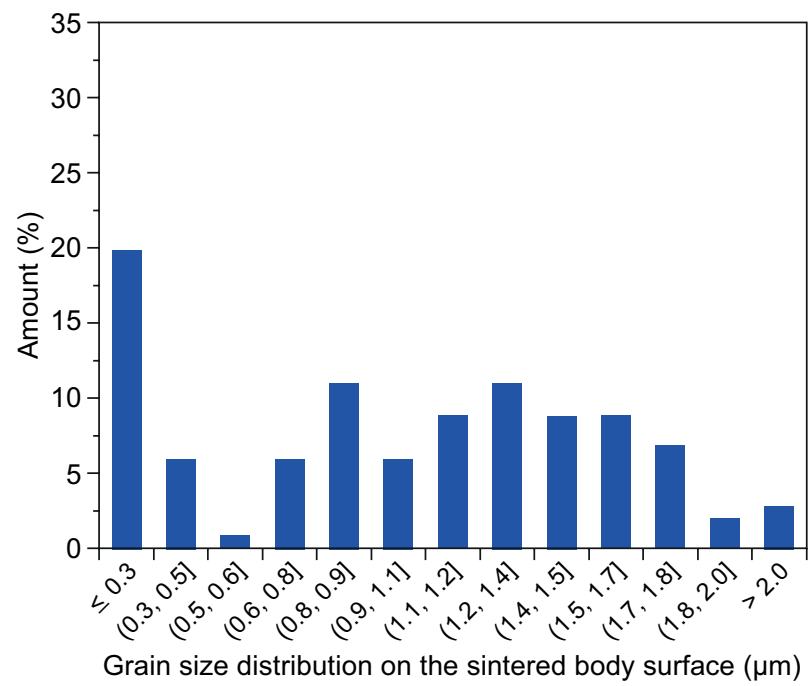

b)

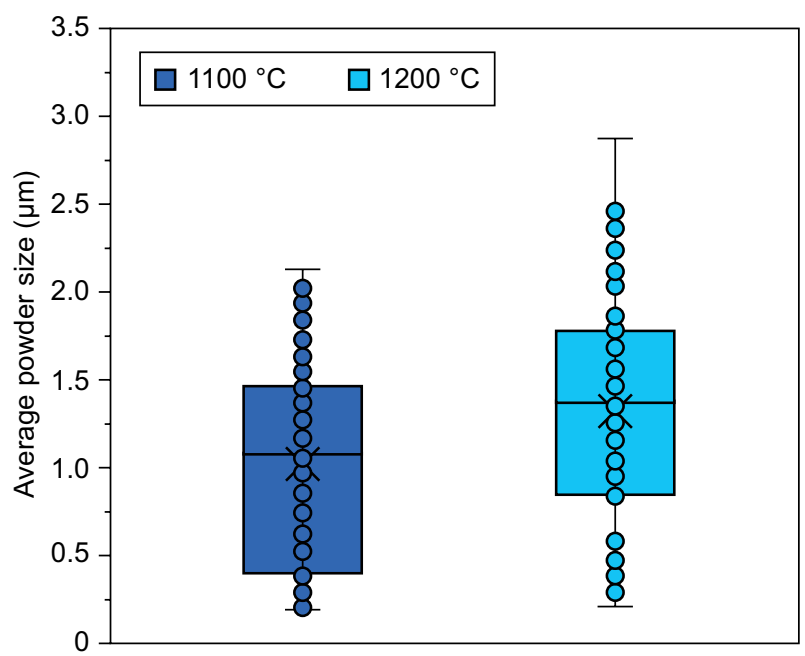

d)

Figure 5. Analysis of the powders and sintered body HA: a) HA powders size distribution, b) grain size distribution of the sintered body, sintering temperature of $1100{ }^{\circ} \mathrm{C}, \mathrm{c}$ ) grain size distribution of the sintered body, sintering temperature of $1200{ }^{\circ} \mathrm{C}$, and d) average grain size of the sintered body. 
meter shrinkage at a sintering temperature of $1000{ }^{\circ} \mathrm{C}$ was $6.50 \%$, and this increased significantly to $16.19 \%$ at a temperature of $1150{ }^{\circ} \mathrm{C}$. The shrinkage diameter continued to increase until the sintering temperature of $1200{ }^{\circ} \mathrm{C}$ at $16.74 \%$ (Table 1 ), but it was not significant. These results are also consistent with previously reported studies $[46,47]$. The increase in the percentage of the shrinkage diameter was due to the shrinking and reduced pores as the sintering temperature increased, as shown in Figure $4 \mathrm{~b}-\mathrm{f}$. Therefore, it can be concluded that sintering was reached at $1150{ }^{\circ} \mathrm{C}$, and it was more perfect at $1200^{\circ} \mathrm{C}$. The weight shrinkage was found to be unchanged and did not affect the increase in the sintering temperature. It occurred uniformly because of the same amount of HA and PVA employed. PVA, as a binder, was thought to have been burned out in the sintering process, as evidenced by the XRD test in Figure 2, where there were no phases other than HA.

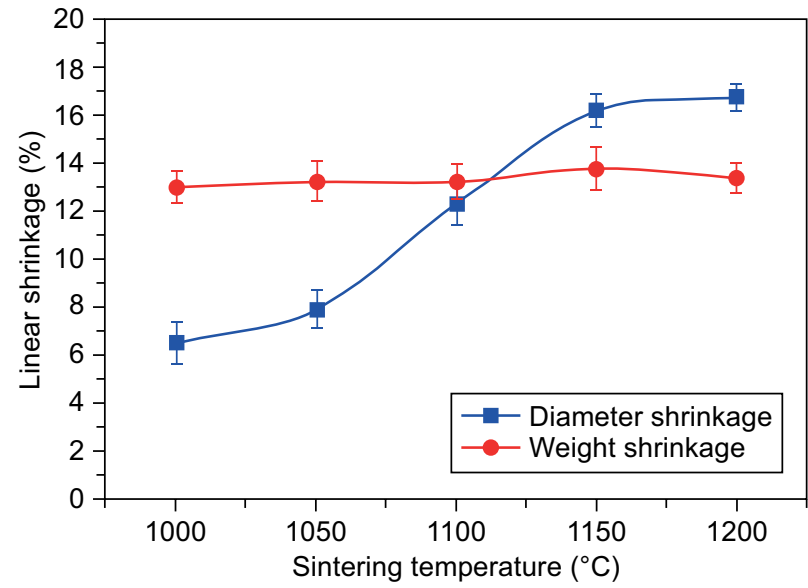

Figure 6. Effect of the sintering temperature on linear shrinkage on the HA sintered bodies.

\section{Density and Relative density}

The density and relative density tests results are shown in Figure 7. The density increased significantly as the sintering temperature increased. The density increased from $2.46 \mathrm{~g} \cdot \mathrm{cm}^{-3}$ at a sintering temperature of $1000{ }^{\circ} \mathrm{C}$ to $3.06 \mathrm{~g} \cdot \mathrm{cm}^{-3}$ at $1200{ }^{\circ} \mathrm{C}$. The same observation was made with regard to the relative density, which rose from $78.0 \%$ at a sintering temperature of $1000{ }^{\circ} \mathrm{C}$ to $97.1 \%$ at
$1200{ }^{\circ} \mathrm{C}$ (Table 1$)$, showing an increase of $24 \%$. Several previous studies reported that a micron-sized HA powder with sintering temperatures ranging from $1000{ }^{\circ} \mathrm{C}$ to $1200{ }^{\circ} \mathrm{C}$ showed an increase in the relative density from $77.3 \%$ to $96 \%$ [25], from $61 \%$ to $96 \%$ [48], and from $76.52 \%$ to $83 \%$ [49]. The increase in the density and relative density occurred due to the increasing sintering temperatures, in which the bonds between the grains occurred more perfectly, while the pores decreased at a sintering temperature of $1200{ }^{\circ} \mathrm{C}$. This statement is also supported by Figure 4b-f, which shows fewer pores in the sintered body with a higher sintering temperature. Figure 8 shows the correlation between the diameter shrinkage

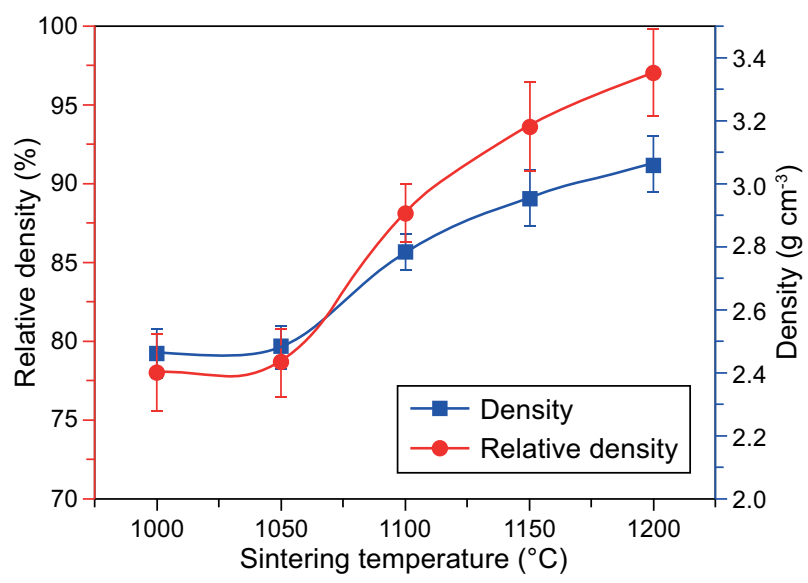

Figure 7. Effect of the sintering temperature on the density and relative density on the HA sintered bodies.

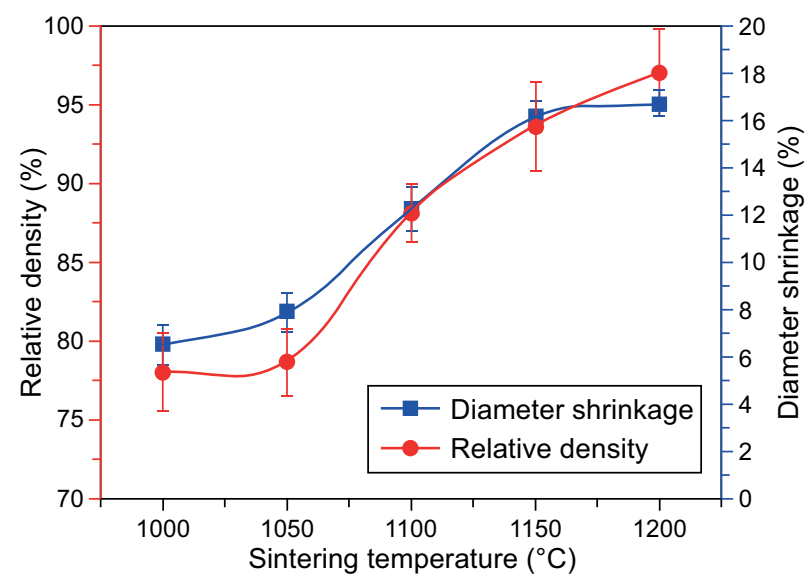

Figure 8. Effect of the sintering temperature on the relative density and diameter shrinkage on the HA sintered bodies.

Table 1. Outlines of the physical and mechanical properties of the HA sintered bodies.

\begin{tabular}{cccccc}
\hline $\begin{array}{c}\text { Sintering } \\
\text { temperature }\left({ }^{\circ} \mathrm{C}\right)\end{array}$ & $\begin{array}{c}\text { Diameter shrinkage } \\
(\%)\end{array}$ & $\begin{array}{c}\text { Weight shrinkage } \\
(\%)\end{array}$ & $\begin{array}{c}\text { Density } \\
\left(\mathrm{g} \cdot \mathrm{cm}^{-3}\right)\end{array}$ & $\begin{array}{c}\text { Relative density } \\
(\%)\end{array}$ & $\begin{array}{c}\text { Vickers hardness } \\
(\mathrm{GPa})\end{array}$ \\
\hline 1000 & $6.50 \pm 0.84$ & $13.01 \pm 0.69$ & $2.46 \pm 0.08$ & $78.0 \pm 2.4$ & $1.23 \pm 0.14$ \\
1050 & $7.88 \pm 0.81$ & $13.23 \pm 0.83$ & $2.48 \pm 0.07$ & $78.7 \pm 2.2$ & $1.74 \pm 0.09$ \\
1100 & $12.30 \pm 0.91$ & $13.22 \pm 0.80$ & $2.78 \pm 0.06$ & $88.2 \pm 1.9$ & $2.67 \pm 0.16$ \\
1150 & $16.19 \pm 0.67$ & $13.78 \pm 0.88$ & $2.96 \pm 0.09$ & $93.7 \pm 2.8$ & $4.40 \pm 0.24$ \\
1200 & $16.74 \pm 0.57$ & $13.39 \pm 0.63$ & $3.06 \pm 0.09$ & $97.1 \pm 2.8$ & $5.67 \pm 0.38$ \\
\hline
\end{tabular}


and the relative density. The high diameter shrinkage causes an increase in the relative density. This can occur if the sintering temperature is at optimal conditions.

\section{Micro hardness}

The results of the hardness testing, which is a mechanical property of the HA sintered bodies, are shown in Figure 9. There was a significant increase in the hardness value from $1.23 \mathrm{GPa}$ at a sintering temperature of $1000{ }^{\circ} \mathrm{C}$ to $5.67 \mathrm{GPa}$ at $1200{ }^{\circ} \mathrm{C}$ (Table 1). Figure 10a shows other evidence indicating that an increase in the sintering temperature to $1200{ }^{\circ} \mathrm{C}$ could reduce the pores and increase the density of the HA sintered bodies. The increase in the hardness was directly proportional to the sintering temperature. This has also been confirmed by several previous studies [50-54]. However, Figure 4b-f proves that with a higher sintering temperature, grain growth will also occur, which can potentially reduce the strength of the sintered body if the sintering temperature exceeds $1200{ }^{\circ} \mathrm{C}$. Other studies also reported that the sintering temperature causes grain growth in the HA sintered body $[55,56]$. Figure $10 \mathrm{~b}$ shows the correlation between the hardness and the linear shrinkage. The linear shrinkage increased as the sintering temperature increased, indicating that increased shrinkage occurred along with the increased sintering temperature, which increases the density of the sintered bodies, thereby increasing the level of hardness. The hardness and linear shrinkage are correlated to the sintering temperature. Other studies have also reported a correlation between the hardness and linear shrinkage to the sintering temperature [25]. Figure 10c shows the correlation between the hardness and the relative density with the sintering temperature. The hardness also correlates to the relative density, where an increase in both values is directly proportional to the increase in the sintering temperature.

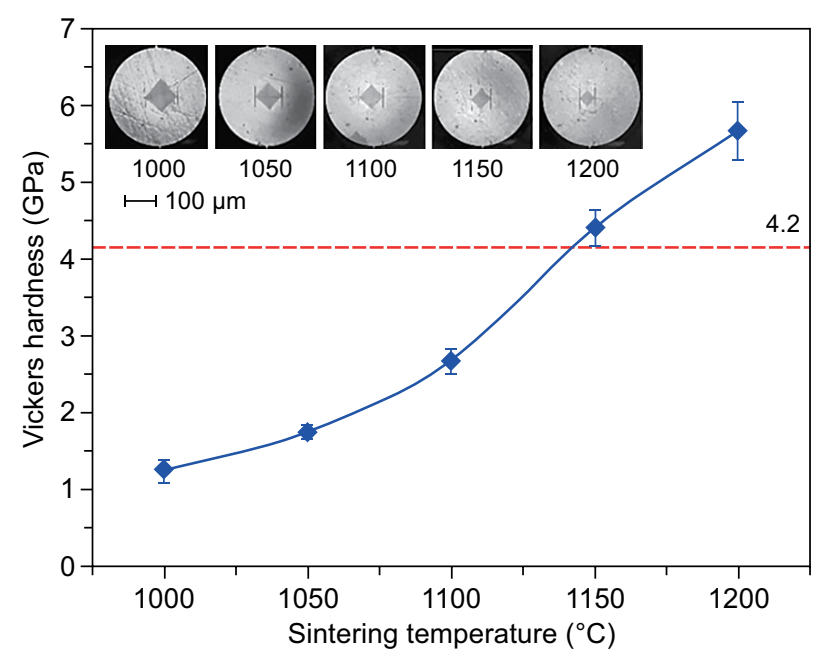

Figure 9. Effect of the sintering temperature on the Vickers hardness on the HA sintered body, the red dotted line is the minimum hardness of the HA [57].
Therefore, it can be concluded that the sintering temperature has a significant influence on the nature of the HA sintered bodies. The correlation between the hardness and relative density has also been reported in several previous studies $[25,56]$. The Vickers hardness
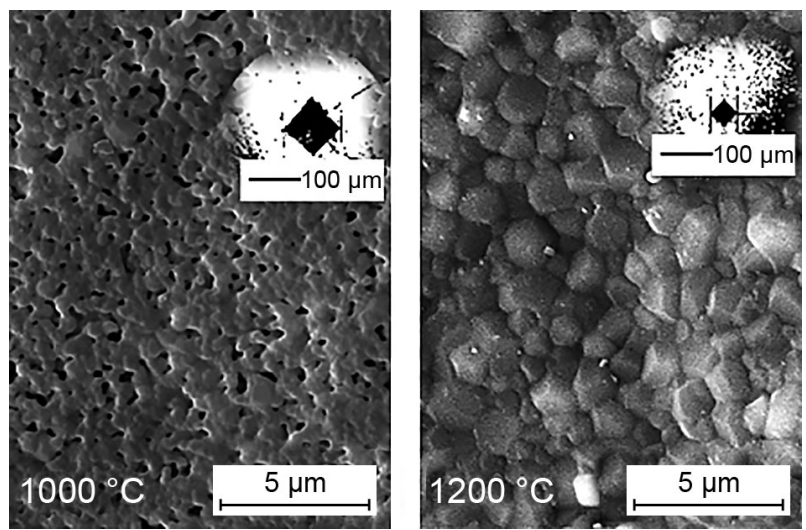

a)

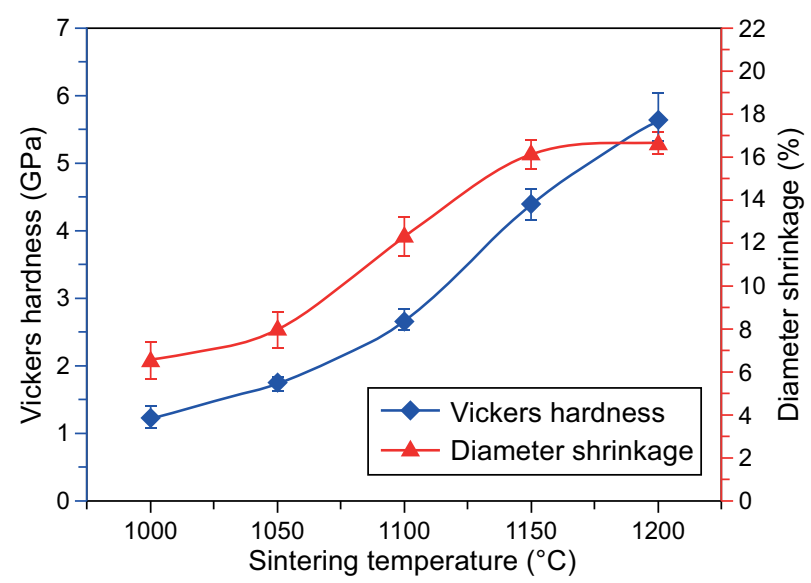

b)

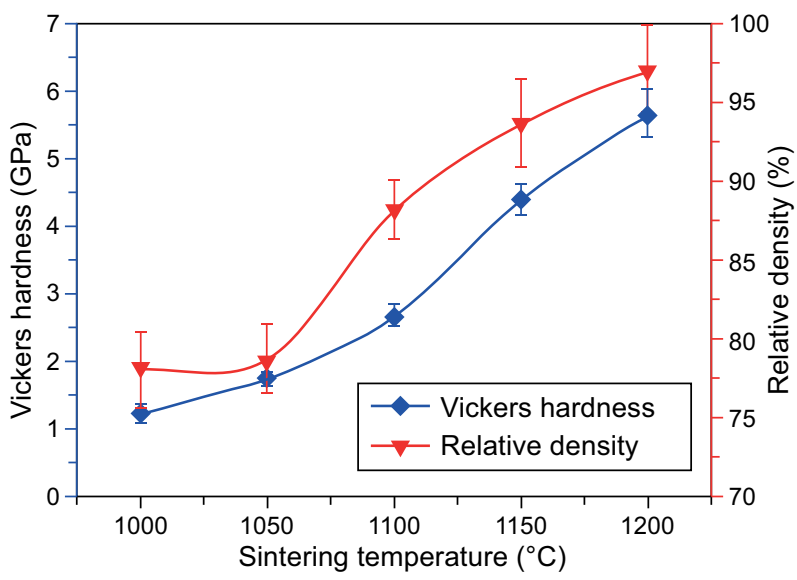

c)

Figure 10. Vickers hardness relationship with the other properties: a) comparison of the microstructure shapes and the Vickers indenter sizes, b) effect of the sintering temperature on the Vickers hardness and diameter shrinkage of the HA sintered bodies, c) effect of the sintering temperature on the Vickers hardness and relative density of the HA sintered bodies. 
Physical and mechanical properties of hydroxyapatite ceramics with a mixture of micron and nano-sized powders: optimising...

Table 2. Data comparison with other studies.

\begin{tabular}{|c|c|c|c|c|c|c|}
\hline Materials & $\begin{array}{c}\text { Sintering } \\
\text { temperature }\left({ }^{\circ} \mathrm{C}\right)\end{array}$ & $\begin{array}{c}\text { Diameter } \\
\text { shrinkage (\%) }\end{array}$ & $\begin{array}{l}\text { Density } \\
\left(\mathrm{g} \cdot \mathrm{cm}^{-3}\right)\end{array}$ & $\begin{array}{c}\text { Relative } \\
\text { density (\%) }\end{array}$ & $\begin{array}{c}\text { Vickers hardness } \\
(\mathrm{GPa})\end{array}$ & References \\
\hline HAp nano & 1250 & - & - & $95.9 \pm 2.64$ & $4.91 \pm 0.06$ & {$[58]$} \\
\hline HAp & 1200 & - & - & - & 4.25 & {$[4]$} \\
\hline $\mathrm{HA} / \beta-\mathrm{TCP}$ & 1200 & 13.11 & 3.23 & - & 5.11 & {$[28]$} \\
\hline HA micron & 1200 & 22 & 3.04 & - & 4.95 & {$[46]$} \\
\hline HA micron & 1200 & 16.69 & 2.86 & - & - & [47] \\
\hline HA micron & 1200 & - & $3.03 \pm 0.03$ & 95.9 & - & [59] \\
\hline HA nano & 1200 & - & 2.86 & - & 4.00 & [60] \\
\hline bHA micron & 1200 & 9.0 & - & 83.0 & 1.50 & [49] \\
\hline HA micron & 1200 & - & - & 97 & 5.6 & {$[56]$} \\
\hline HA micron & 1250 & - & - & 98.5 & 5.9 & - \\
\hline HA nano & 1300 & - & 2.9 & 94 & 4.25 & {$[61]$} \\
\hline HA & 1100 & - & - & - & 4 & {$[62]$} \\
\hline HA micron:nano & 1200 & $16.74 \pm 0.57$ & $3.06 \pm 0.09$ & $97.1 \pm 2.8$ & $5.67 \pm 0.38$ & Present study \\
\hline
\end{tabular}

on the HA sintered at temperatures of $1150{ }^{\circ} \mathrm{C}$ and $1200{ }^{\circ} \mathrm{C}$, namely $4.40 \mathrm{GPa}$ and $5.67 \mathrm{GPa}$, respectively, met the standard for HA hardness in the range of 4.2-7.2 GPa [57]. All the data supported the observation that the mixture of the micron- and nano-sized HA at a ratio of 80:20 wt. \% has a sintering temperature between $1150{ }^{\circ} \mathrm{C}$ and $1200{ }^{\circ} \mathrm{C}$. Table 2 shows a comparison of the physical and mechanical properties of this study with several other studies.

\section{CONCLUSION}

The optimum sintering temperature of the mixture of micron- and- nano-sized commercial HA powders at a ratio of $80: 20 \mathrm{wt} . \%$ is in the range from 1150 to $1200{ }^{\circ} \mathrm{C}$. Good grain boundaries began to occur at a sintering temperature of $1150^{\circ} \mathrm{C}$ and were fully formed at $1200^{\circ} \mathrm{C}$, as indicated by the constant linear shrinkage observed in these sintering temperatures. While, at temperatures from $1000{ }^{\circ} \mathrm{C}$ to $<1150{ }^{\circ} \mathrm{C}$, the grain boundaries between the particles are relatively low, as evidenced by the high number of pores, low relative density, low linear shrinkage, and low hardness. The mechanical properties are maintained high at sintering temperatures of $1150^{\circ} \mathrm{C}$ and $1200{ }^{\circ} \mathrm{C}$, i.e., Vickers hardness values of $4.40 \mathrm{GPa}$ and $5.67 \mathrm{GPa}$, respectively. The FESEM image also proved the decrease in the number and size of pores and there was no significant grain growth, along with an increase in the sintering temperature. There was no phase change in the HA sintered bodies for each variation of the sintering temperature.

\section{Acknowledgment}

This research was funded by a Doctoral Dissertation Research Grant of the Ministry of Research and Technology/National Research and Innovation Agency of the Republic of Indonesia with contract No. 163/SP2H/ AMD/LT/DRPM/2020. While, publication of this article was supported by Engineering Faculty of Universitas Andalas under 2021 publication grant.

\section{REFERENCES}

1. García Domínguez G., Garrido Hernández A., Cerón Montes G., Morales Ramírez A.J., de la Torre. (2019): Structural and luminescent properties of europium-doped and undoped hydroxyapatite powders sintered by spark plasma. Ceramics - Silikaty, 63, 100-109. doi: 10.13168/ cs.2019.0002.

2. Nuswantoro N.F., Gunawarman, Saputra M.R., Nanda I.P., Idris M.H., Arafat A. (2018): Microstructure analysis of hydroxyapatite coating on stainless steel 316L using investment casting technique for implant application. International Journal on Advanced Science, Engineering and Information Technology, 8, 2168-2174. doi: 10.18517/ ijaseit.8.5.5808.

3. Ivanova A.A., Surmeneva M.A., Tyurin A.I., Surmenev R.A. (2018): Correlation between structural and mechanical properties of RF magnetron sputter deposited hydroxyapatite coating. Materials Characterization, 142, 261-269. doi: 10.1016/j.matchar.2018.05.042.

4. Belamri D., Harabi A., Karbouaa N., Benyahia N. (2020): The effect of KF on the structural evolution of natural hydroxyapatite during conventional and microwave sintering. Ceramics International, 46, 1189-1194. doi: 10.1016/j. ceramint.2019.09.091.

5. Ahmad Khiri M.Z., Matori K.A., Mohd Zaid M.H., Che Abdullah C.A., Zainuddin N., Alibe I.M., Abdul Rahman N.A., Abdul Wahab S.A. (2019): The effect of the $\mathrm{pH}$ values and sintering temperatures on the physical, structural and mechanical properties of nano hydroxyapatite derived from ark clam shells (Anadara granosa) prepared via the wet chemical precipitate method. Ceramics - Silikaty, 63, 194-203. doi: 10.13168/cs.2019.0011.

6. Pabst W., Uhlírová T. (2017): A generalized class of transformation matrices for the reconstruction of sphere size distributions from section circle size distributions. Ceramics - Silikaty, 61, 147-157. doi: 10.13168/cs.2017.0010.

7. Juliadmi D., Fauzi V.R., Gunawarman, Nur H., Idris M.H. 
(2017): Hydroxyapatite coating on titanium alloy Ti-6Al-4V with electrophoretic deposition (EPD) for dental root application. International Journal on Advanced Science, Engineering and Information Technology, 7, 2152-2158.

8. Subramanian R., Sathish S., Murugan P., Mohamed Musthafa A., Elango M. (2019) Effect of piperine on size, shape and morphology of hydroxyapatite nanoparticles synthesized by the chemical precipitation method. Journal of King Saud University - Science, 31, 667-673. doi: 10.1016/j.jksus.2018.01.002.

9. Chen M., Zhang H., Shan S., Li Y., Li X., Peng D. (2020): Fabrication of multiwalled carbon nanotubes/carrageenanchitosan@ Ce and Sr substituted hydroxyapatite biocomposite coating on titanium: In vivo bone formation evaluations. Journal of King Saud University - Science, 32, 1175-1181. doi: 10.1016/j.jksus.2019.11.006.

10. Sun J., Zheng X., Li H., Fan D., Song Z., Ma H., Hua X., Hui J. (2017): Monodisperse selenium-substituted hydroxyapatite: Controllable synthesis and biocompatibility. Materials Science and Engineering C, 73, 596-602. doi: 10.1016/j.msec.2016.12.106.

11. Indra A., Hadi F., Mulyadi I.H., Affi J., Gunawarman (2021): Effect of rock sugar as a pore-forming material on the physical and mechanical properties of hydroxyapatite scaffold. IOP Conference Series: Materials Science and Engineering, 1041, 012049. doi: 10.1088/1757-899x/1041/ $1 / 012049$.

12. Kumari R., Majumdar J.D. (2017): Microstructure and surface mechanical properties of plasma spray deposited and post spray heat treated hydroxyapatite (HA) based composite coating on titanium alloy (Ti-6Al-4V) substrate. Materials Characterization, 131, 12-20. doi: 10.1016/j. matchar.2017.06.011.

13. Gunduz O., Yetmez M., Ekren N., Kilic O., Ben-Nissan B., Oktar F.N. (2018): Microstructural and mechanical properties of nano-yttria-oxide doped hydroxyapatite composites. Materials Science Forum, 923 MSF, 89-92. doi: 10.4028/www.scientific.net/MSF.923.89.

14. Xue W., Chen P., Wang F., Wang L. (2019): Melt spinning of nano-hydroxyapatite and polycaprolactone composite fibers for bone scaffold application. Journal of Materials Science, 54, 8602-8612. doi: 10.1007/s10853-019-03475-y.

15. Zeng H., Jin X., Xiong Y. (2019): Enhanced Hardness of Transparent HAp Ceramic by Microstructure Refinement. Journal Wuhan University of Technology, Materials Science Edition, 34, 254-258. doi: 10.1007/s11595-019-2043-9.

16. Brzezińska-Miecznik J., Haberko K., Sitarz M., Bućko M.M., MacHerzyńska B., Lach R. (2016): Natural and synthetic hydroxyapatite/zirconia composites: A comparative study. Ceramics International, 42, 11126-11135. doi: 10.1016/j.ceramint.2016.04.019.

17. Bernik S., Podlogar M., Rustja S., Cergolj M. (2017): Influence of granulate and pressure on green compacts and the current-voltage characteristics of sintered $\mathrm{ZnO}$-based varistor ceramics. Informacije MIDEM, 47, 171-177.

18. Huang S.J., Ye C.S., Zhao H.P., Fan Z.T. (2020): Parameters optimization of binder jetting process using modified silicate as a binder. Materials and Manufacturing Processes, 35, 214-220. doi: 10.1080/10426914.2019.1675890.

19. Es-Saddik M., Laasri S., Taha M., Laghzizil A., Hajjaji A., Hlil E.K. (2019): Development and characterization of hydroxyapatite-alumina biocomposites for orthopedic implants. Key Engineering Materials, 820, 97-103. doi:
10.4028/www.scientific.net/KEM.820.97.

20. Shahbaz A., Esmaeilian M., Nasr R., Gavanji K. (2019): Effect of MgF2 Addition on the Mechanical Properties of Hydroxyapatite Synthesized via Powder Metallurgy. Journal of Composites and Compounds, 1(1), 16-21. doi: $10.29252 /$ jcc. 1.1 .3

21. Indra A., Edison E., Nofrianto H. (2018): Optimization of compaction pressure on brick. MATEC Web of Conferences, 215, 1-5. doi: 10.1051/matecconf $/ 201821501025$.

22. Wei Q., Wang Y., Chai W., Zhang Y., Chen X. (2017): Molecular dynamics simulation and experimental study of the bonding properties of polymer binders in $3 \mathrm{D}$ powder printed hydroxyapatite bioceramic bone scaffolds. Ceramics International, 43, 13702-13709. doi: 10.1016/j.ceramint.2017.07.082.

23. Cai X., Tong H., Shen X., Chen W., Yan J., Hu J. (2009): Preparation and characterization of homogeneous chitosan-polylactic acid/hydroxyapatite nanocomposite for bone tissue engineering and evaluation of its mechanical properties. Acta Biomaterialia, 5, 2693-2703. doi: 10.1016/j. actbio.2009.03.005.

24. Indra A., Firdaus R., Mulyadi I.H., Affi J., Gunawarman (2020): Enhancing the physical and mechanical properties of pellet-shaped hydroxyapatite by controlling micronand nano-sized powder ratios. Ceramics International, 46, 15882-15888. doi: 10.1016/j.ceramint.2020.03.136.

25. Muralithran G., Ramesh S. (2000): The Effects of sintering temperature on the properties of hydroxyapatite. Ceramics International, 26, 221-230. doi: 10.1016/S0272-8842 (99)00046-2.

26. Safarzadeh M., Chee C.F., Ramesh S., Fauzi M.N.A. (2020): Effect of sintering temperature on the morphology, crystallinity and mechanical properties of carbonated hydroxyapatite (CHA). Ceramics International, 46, 26784-26789. doi: 10.1016/j.ceramint.2020.07.153.

27. Saiz E., Gremillard L., Menendez G., Miranda P., Gryn K., Tomsia A.P. (2007): Preparation of porous hydroxyapatite scaffolds. Materials Science and Engineering C, 27, 546-550. doi: 10.1016/j.msec.2006.05.038.

28. Khiri M.Z.A., Matori K.A., Zaid M.H.M., Abdullah C.A.C., Zainuddin N., Alibe I.M., Rahman N.A.A., Wahab S.A.A., Azman A.Z.K., Effendy N. (2019): Crystallization behavior of low-cost biphasic hydroxyapatite/ $\beta$-tricalcium phosphate ceramic at high sintering temperatures derived from high potential calcium waste sources. Results in Physics, 12, 638-644. doi: 10.1016/j.rinp.2018.12.025.

29. Du W., Ren X., Ma C., Pei Z. (2019): Ceramic binder jetting additive manufacturing: Particle coating for increasing powder sinterability and part strength. Materials Letters, 234, 327-330. doi: 10.1016/j.matlet.2018.09.118.

30. Esmaeilkhanian A., Sharifianjazi F., Abouchenari A., Rouhani A., Parvin N., Irani M. (2019): Synthesis and Characterization of Natural Nano-hydroxyapatite Derived from Turkey Femur-Bone Waste. Applied Biochemistry and Biotechnology, 189, 919-932. doi: 10.1007/s12010-01903046-6.

31. Barabashko M.S., Tkachenko M. V., Neiman A.A., Ponomarev A.N., Rezvanova A.E. (2019): Variation of Vickers microhardness and compression strength of the bioceramics based on hydroxyapatite by adding the multi-walled carbon nanotubes. Applied Nanoscience, 10, 2601-2608. doi: 10. 1007/s13204-019-01019-z.

32. Pazarlioglu S., Salman S. (2019): Effect of lanthanum 
oxide additive on the sinterability, physical/mechanical, and bioactivity properties of hydroxyapatite-alpha alumina composite. Journal of the Australian Ceramic Society, 55, 1195-1205. doi: 10.1007/s41779-019-00336-4.

33. Singh M.K., Zafar S., Talha M. (2019): Development of porous bio-composites through microwave curing for bone tissue engineering. Materials Today: Proceedings, 18 , 731-739. doi: 10.1016/j.matpr.2019.06.478.

34. Pingan H., Mengjun J., Yanyan Z., Ling H. (2017): A silica/ PVA adhesive hybrid material with high transparency, thermostability and mechanical strength. RSC Advances, 7, 2450-2459. doi: 10.1039/C6RA25579E.

35. Victoria E.C., C. Robinson M. (2019): Comparative studies on synthesis and sintering studies of biologically derived hydroxyapatite from Capria hircus (Goat) and Bos primigenius (Bovine). Vacuum, 160, 378-383. doi: 10. 1016/j.vacuum.2018.11.019.

36. Mallik P.K., Balani K., Basu B. (2019): Nano indentation Analysis of Multi Stage Spark Plasma Sintered Hydroxyapatite-Calcium Titanate Biocomposite. International Journal of Engineering Sciences, 12, 8-14. doi: 10.36224/ ijes.120102.

37. Ramesh S., Natasha A.N., Tan C.Y., Bang L.T., Ramesh S., Ching C.Y., Chandran H. (2016): Direct conversion of eggshell to hydroxyapatite ceramic by a sintering method. Ceramics International, 42, 7824-7829. doi: 10.1016/j. ceramint.2016.02.015.

38. Palacio C., Jaramillo D., Correa S., Arroyave M. (2017): Study of the suitability of a commercial hydroxyapatite powder to obtain sintered compacts for medical applications. Journal of Physics: Conference Series, 850, 012021. doi: 10.1088/1742-6596/850/1/012021.

39. Sun R.X., Lv Y., Niu Y.R., Zhao X.H., Cao D.S., Tang J., Sun X.C., Chen K.Z. (2017): Physicochemical and biological properties of bovine-derived porous hydroxyapatite/ collagen composite and its hydroxyapatite powders. Ceramics International, 43, 16792-16798. doi: 10.1016/j.ceramint.2017.09.075.

40. Liu D., Wu Y., Wu H., Li X., Yang X., Zhu X., Zhang X. (2019): Effect of process parameters on the microstructure and property of hydroxyapatite precursor powders and resultant sintered bodies. International Journal of Applied Ceramic Technology, 16, 444-454. doi: 10.1111/ijac.13097.

41. Ramirez-Gutierrez C.F., Londoño-Restrepo S.M., del Real A., Mondragón, Rodriguez-García M.E. (2017): Effect of the temperature and sintering time on M.A. the thermal, structural, morphological, and vibrational properties of hydroxyapatite derived from pig bone. Ceramics International, 43, 7552-7559. doi: 10.1016/j.ceramint. 2017.03.046.

42. Yetmez M., Erkmen Z.E., Kalkandelen C., Ficai A., Oktar F.N. (2017): Sintering effects of mullite-doping on mechanical properties of bovine hydroxyapatite. Materials Science and Engineering C, 77, 470-475. doi: 10.1016/j. msec.2017.03.290.

43. Shi X., Zhou J., Liu G., Wang L. (2017): The Physical and Antimicrobial Properties of Silver Doped Hydroxyapatite Sintered by Microwave and Conventional Sintering. Journal of Inorganic and Organometallic Polymers and Materials, 27, 955-961. doi: 10.1007/s10904-017-0542-8.

44. Obada D.O., Dauda E.T., Abifarin J.K., Dodoo-Arhin D., Bansod N.D. (2020): Mechanical properties of natural hydroxyapatite using low cold compaction pressure: Effect of sintering temperature. Materials Chemistry and Physics,
239, 122099. doi: 10.1016/j.matchemphys.2019.122099.

45. Pazarlloglu S., Salman S. (2017): Sintering effect on the microstructural, mechanical, and in vitro bioactivity properties of a commercially synthetic hydroxyapatite. Journal of the Australian Ceramic Society, 53, 391-401. doi: 10. 1007/s41779-017-0048-4.

46. Chen P.Y., Wang S.F., Chien R.R., Tu C.S., Feng K.C., Chen C.S., Hung K.Y., Schmidt V.H. (2019): Evolution of the microstructural and mechanical properties of hydroxyapatite bioceramics with varying sintering temperature. Ceramics International, 45, 16226-16233. doi: 10.1016/j. ceramint.2019.05.144.

47. Khiri M.Z.A., Matori K.A., Zainuddin N., Abdullah C.A.C., Alassan Z.N., Baharuddin N.F., Zaid M.H.M. (2016): The usability of ark clam shell (Anadara granosa) as calcium precursor to produce hydroxyapatite nanoparticle via wet chemical precipitate method in various sintering temperature. SpringerPlus, 5(1), 1-15. doi: 10.1186/s40064-0162824-y.

48. Ruys A.J., Wei M., Sorrell C.C., Dickson M.R., Brandwood A., Milthorpe B.K. (1995): Sintering effects on the strength of hydroxyapatite. Biomaterials, 16, 409-415. doi: 10.1016/ 0142-9612(95)98859-C.

49. Herliansyah M.K., Hamdi M., Ide-Ektessabi A., Wildan M.W., Toque J.A. (2009): The influence of sintering temperature on the properties of compacted bovine hydroxyapatite. Materials Science and Engineering C,29, 1674-1680. doi: 10.1016/j.msec.2009.01.007.

50. Hariani P.L., Said M., Salni (2019): Effect of sintering on the mechanical properties of hydroxyapatite from fish bone (Pangasius Hypophthalmus). IOP Conference Series: Materials Science and Engineering, 509, 012109. doi: 10.1088/1757-899X/509/1/012109.

51. Ramesh S., Loo Z.Z., Tan C.Y., Chew W.J.K., Ching Y.C., Tarlochan F., Chandran H., Krishnasamy S., Bang L.T., Sarhan A.A.D. (2018): Characterization of biogenic hydroxyapatite derived from animal bones for biomedical applications. Ceramics International, 44, 10525-10530. doi: 10.1016/j.ceramint.2018.03.072.

52. Catalgol Z. (2019): Sintering effect on borosilicate glass-bovine hydroxyapatite composites. Journal of the Australian Ceramic Society, 55, 1075-1079. doi: 10.1007/ s41779-019-00320-y.

53. Bellucci D., Desogus L., Montinaro S., Orrù R., Cao G., Cannillo V. (2017): Innovative hydroxyapatite/bioactive glass composites processed by spark plasma sintering for bone tissue repair. Journal of the European Ceramic Society, 37, 1723-1733. doi: 10.1016/j.jeurceramsoc.2016.11.012.

54. Bonadio T.G.M., Fiorentin E.R., Candido A.G., Miyahara R.Y., Freitas V.F., Kiyochi H.J., Hernandes L., Rosso J.M., Burato J.A., Santos I.A., Baesso M.L., Weinand W.R. (2020): Enhanced mechanical properties and osseointegration features of $\mathrm{CaNb}_{2} \mathrm{O} 6-\mathrm{PNb}_{9} \mathrm{O}_{25}-\mathrm{Ca}_{3}\left(\mathrm{PO}_{4}\right)_{2}$ triphasic nanostructured bioceramics derived by optimised sinterization of $\mathrm{Nb}_{2} \mathrm{O}_{5}$ and natural hydroxyapatite- $\beta$-tricalcium phosphate. Ceramics International, 46, 12837-12845. doi: 10.1016/j.ceramint.2020.02.054.

55. Chadha R.K., Singh A.P., Singh K.L., Sharma C., Naithani V. (2019): Influence of microwave processing and sintering temperature on the structure and properties of $\mathrm{Sr} / \mathrm{Zr}$ doped hydroxyapatite. Materials Chemistry and Physics, 223, 319-324. doi: 10.1016/j.matchemphys.2018.09.086.

56. Amiri Roudan M., Ramesh S., Niakan A., Wong Y.H., 
Akhtari Zavareh M., Chandran H., Teng W.D., Lwin N., Sutharsini U. (2017): Thermal phase stability and properties of hydroxyapatite derived from biowaste eggshells. Journal of Ceramic Processing Research, 18, 69-72.

57. Sara Lee K.Y., Christopher Chin K.M., Ramesh S., Tan C.Y., Teng W.D., Sopyan I. (2012): Characterization of forsterite bioceramics. Advanced Materials Research, 576, 195-198. doi: 10.4028/www.scientific.net/AMR.576.195.

58. Nie J., Zhou J., Huang X., Wang L., Liu G., Cheng J. (2019): Effect of $\mathrm{TiO}_{2}$ doping on densification and mechanical properties of hydroxyapatite by microwave sintering. Ceramics International, 45, 13647-13655. doi: 10.1016/j. ceramint.2019.04.007.

59. Nasker P., Samanta A., Rudra S., Sinha A., Mukhopadhyay A.K., Das M. (2019): Effect of fluorine substitution on sintering behaviour, mechanical and bioactivity of hydroxyapatite. Journal of the Mechanical Behavior of Biomedical
Materials, 95, 136-142. doi: 10.1016/j.jmbbm.2019.03.032. 60. Inthong S., Sweatman D.R., Eitssayeam S., Tunkasiri T. (2019): Influence of sintering temperature on physical and mechanical properties of hydroxyapatite-calcium titanate composite. Key Engineering Materials, 805 KEM, 65-70. doi: 10.4028/www.scientific.net/KEM.805.65.

61. Tavangar M., Heidari F., Hayati R., Tabatabaei F., Vashaee D., Tayebi L. (2019): Manufacturing and characterization of mechanical, biological and dielectric properties of hydroxyapatite-barium titanate nanocomposite scaffolds. Ceramics International, 46, 9086-9095. doi: 10.1016/j. ceramint.2019.12.157.

62. Khoshsima S., Yilmaz B., Tezcaner A., Evis Z. (2016): Structural, mechanical and biological properties of hydroxyapatite-zirconia-lanthanum oxide composites. Ceramics International, 42, 15773-15779. doi: 10.1016/j.ceramint. 2016.07.041. 